\title{
EDUKASI SENAM KAKITERHADAP KEMAMPUAN MELAKUKAN SENAM KAKI PADA PENDERITA DIABETES MELITUS TIPE 2 DI PUSKESMAS KERENG BANGKIRAI PALANGKA RAYA
}

\author{
Yuyun Christyann ${ }^{1} \mathbf{i}$, Novi Mery Kala Aheng ${ }^{2}$, Yongwan Nyamin ${ }^{3}$ \\ 1,2,3Politeknik Kesehatan Kemenkes Palangka Raya \\ Email: yuyun.christyanni@gmail.com
}

\begin{abstract}
ABSTRAK
Angka kejadian Diabetes Melitus menunjukkan prevalensi yang semakin meningkat dewasa ini. Kondisi ini salah satunya dipengaruhi oleh kurangnya pengetahuan klien dalam piñata laksanaan Diabetes Melitus. Upaya meningkatkan pengetahuan dapat dilakukan melalui edukasi dengan menggunakan media dan metode yang efektif. Penggunaan media audiovisual dipercaya sebagai media yang paling efektif dalam menyampaikan informasi. Edukasi dalam penelitian ini menggunakan media audio visual yang diterapkan bersama dengan metode demonstrasi. Tujuan penelitian ini adalah menganalisis pengaruh edukasi dengan media audio visual dan metode demonstrasi terhadap kemampuan melakukan senam kaki pada penderita Diabetes Melitus Tipe 2 di wilayah kerja Puskesmas Kereng Bangkirai Palangka Raya. Metode penelitian yang digunakan adalah quasy experiment dengan one group pre and post test design. Teknik pengambilan sampel dilakukan dengan purposive sampling sebanyak 30 orang.Hasil penelitian menunjukkan terdapat perbedaan pengetahuan dan kemampuan melakukan senam kaki pada sebelum dan sesudah dilakukan edukasi yang ditunjukkan dari hasil uji paired t-test didapatkan nilai $p=0,000<\alpha=0,05$. Edukasi senam kaki dengan media audio visual dan demonstrasi berpengaruh terhadap kemampuan melakukan senam kaki pada penderita Diabetes Melitus Tipe 2 di wilayah kerja Puskesmas Kereng Bangkirai.
\end{abstract}

Kata kunci: edukasi, senam kaki, media audiovisual, metode demonstrasi

\begin{abstract}
The incidence of diabetes mellitus shows an increasing prevalence today. This condition is influenced by the lack of knowledge of clients in the management of Diabetes Mellitus. Efforts to increase knowledge can be done through education using media and effective methods. The use of audiovisual media is believed to be the most effective media in conveying information. Education in this study used audiovisual media that was applied in conjunction with the demonstration method. The purpose of this study was to analyze the effect of education with audiovisual media and demonstration methods on the ability to do foot exercises in patients with Type 2 Diabetes Mellitus in the work area of KerengBangkirai Health Center, Palangka Raya. The research method used was a quasy experiment with one group pre and post test design. The sampling technique was done by purposive sampling as many as 30 peoples.
\end{abstract}


The results showed that there were differences in knowledge and ability to do foot exercise before and after the education which was shown from the results of the paired t-test obtained $p$ value $=0,000<\alpha=0.05$. Foot exercise education with audiovisual media and demonstrations had an effect on the ability to do foot exercise in patients with Type 2 Diabetes Mellitus in the working area of KerengBangkirai Health Center.

Keywords: education, foot exercises, audiovisual media, demonstration methods

\section{PENDAHULUAN}

Perubahan pola penyakit di negara berkembang telah berubah dari penyakit menular menjadi penyakit tidak menular. Salah satu jenis penyakit tidak menular tersebut adalah penyakit degeneratif. Diabetes Melitus merupakan salah satu penyakit degeneratif yang diperkirakan akan terus meningkat. Meningkatnya prevalensi diabetes melitus di beberapa negara berkembang diakibatkan oleh peningkatan kemakmuran, peningkatan pendapatan perkapita dan perubahan gaya hidup [1]

Menurut World Health Organization (WHO) sebanyak 422 juta orang dewasa di dunia dengan usia diatas 18 tahun mengalami Diabetes Melitus. Prevalensi penderita Diabetes Melitus di Asia Tenggara diperkirakan mencapai $4,3 \%$ dari 227 juta orang dengan jumlah penderita sebanyak 96 juta orang, sedangkan di kawasan pasific barat 5,7\% dari 227 juta orang dengan jumlah penderita sebanyak 131 juta orang [2]. Prevalensi penderita Diabetes Melitus di Indonesia menempati urutan ke 7 di dunia pada tahun 2015. WHO memprediksi penderita Diabetes Melitus di Indonesia jumlahnya akan meningkat dari 8,4 juta orang pada tahun 2000 menjadi 21,3 juta orang pada tahun 2030.

Peningkatan kadar glukosa darah yang tidak terkontrol pada pasien Diabetes Melitus dapat mengakibatkan terjadinya komplikasi pada organ tubuh antara lain ginjal, mata, sistem vaskular, dan kerusakan pembuluh darah perifer tungkai yang biasa disebut dengan kaki diabetes [3]. Menurut Waspadji (2014) dalam jurnal penelitian Refrensi [4] kaki diabetes merupakan salah satu infeksi kronik Diabetes Melitus yang paling ditakuti dan akan berakhir dengan kecacatan (amputasi) dan kematian. Perawatan kaki yang baik mampu menurunkan kasus kecacatan dan kematian yang mengancam kehidupan. Melakukan perawatan kaki secara teratur dapat mengurangi penyakit kaki diabetik sebesar 50-60\%. Peningkatkan vaskularisasi perawatan kaki dapat juga dilakukan dengan gerakan-gerakan kaki yang dikenal sebagai senam kaki diabetes. Senam kaki diabetes dapat membantu 
sirkulasi darah dan memperkuat otot-otot kecil kaki dan mencegah terjadinya kelainan bentuk kaki, mengatasi keterbatasan jumlah insulin pada penderita Diabetes Melitus mengakibatkan kadar gula dalam darah meningkat hal ini menyebabkan rusaknya pembuluh darah dan saraf [4].

Penderita diabetes sangat membutuhkan peningkatan pengetahuan melalui edukasi yang tepat. Pemahaman terhadap kondisi kesehatan serta bagaimana menjalani kehidupan pasca di diagnosa penyakit diabetes melitus dapat membantu dalam meningkatkan kualitas hidup yang lebih baik .Edukasi diabetes adalah pendidikan dan pelatihan mengenai pengetahuan dan keterampilan bagi penderita diabetes melitus yang bertujuan untuk menunjang perubahan perilaku untuk meningkatkan pemahaman tentang penyakit diabetes. Edukasi merupakan masalah satu pilar pengelolaan diabetes melitus yang bertujuan memberikan pemahaman mengenai penyakit, pencegahan, tanda gejala, dan penatalaksanaan diabetes melitus salah satunya dengan senam kaki diabetes [1].

Menurut Tjahyono (2013) dalam penelitian Refrensi [5] tentang pengaruh pendidikan kesehatan senam kaki melalui media audiovisual terhadap pengetahuan pelaksanaan senam kaki pada pasien DM tipe 2 menyebutkan bahwa edukasi melalui media audio visual mempengaruhi pengetahuan dan kepatuhan pasien DM tipe 2. Penelitian serupa yang dilakukan oleh [6] menyimpulkan bahwa terdapat pengaruh penyuluhan kesehatan dengan media audio visual terhadap penurunan tingkat kecemasan pada pasien DM setelah diberikan penyuluhan kesehatan.

Menurut penelitian [5] tentang pengaruh pendidikan kesehatan senam kaki melalui media audiovisual terhadap pengetahuan pelaksanaan senam kaki pada pasien DM tipe 2 menyebutkan pemberian pendidikan kesehatan melalui media audiovisual efektif terhadap pengetahuan pelaksanaan senam kaki pada pasien DM tipe 2 dengan hasil nilai $p$ value $(0,002)<\alpha$ $(0,05)$.

Penderita Diabetes Melitus di Kalimantan Tengah setiap tahunnya mengalami peningkatan, untuk menekan tingginya kasus Diabetes Melitus dan mencegah komplikasi kaki diabetes diperlukan peningkatan pengetahuan masyarakat mengenai penatalaksanaan Diabetes Melitus dengan cara pemberian edukasi mengenai senam kaki diabetes dengan media audiovisual. Peneliti tertarik untuk melakukan penelitian tentang edukasi senam kaki dengan media audiovisual dan metode demonstrasi terhadap kemampuan 
melakukan senam kaki pada penderita Diabetes Melitus Tipe 2. Perbedaan penelitian ini dengan sebelumnya yaitu peneliti menggabungkan teknik pembelajaran edukasi audiovisual dengan metode demonstrasi untuk hasil akhir penelitian dapat dilihat dari pengetahuan dan kemampuan penderita diabetes dalam melakukan senam kaki.

\section{METODOLOGI}

Desain yang digunakan dalam penelitian ini adalah quasi experiment dengan one group pre and post test design. Populasi dalam penelitian ini adalah semua penderita Diabetes Melitus tipe 2 di Wilayah kerja Puskesmas Kereng Bangkirai Palangka Raya.Sampel dalam penelitian ini adalah 30 orang penderita Diabetes Melitus tipe 2 di Wilayah Kerja Puskesmas Kereng Bangkirai Palangka Raya yang diambil dengan teknik purposive sampling dan memenuhi kriteria inklusi penderita Diabetes Melitus Tipe 2, berusia 20 sampai dengan 60 tahun, bersedia secara suka rela menjadi responden, bersedia mengisi informed consent menjadi responden, dapatmembaca, menulis dan mendengar, berpendidikan minimal SMP dan maksimal SMAdantidak memiliki komplikasi serius (retinopati, gangren/ulkus diabetikum, gagal ginjal kronis, Congestive Heart Failure (CHF). Sedangkan kriteria eksklusi sampel adalah responden yang sedang di rawat di Rumah Sakit, pikun, sedang bepergian dalam waktu lama dan responden yang tidak mengikuti jalannya penelitian sejak awal hingga akhir sesi.

\section{HASIL DAN PEMBAHASAN}

\section{AnalisisUnivariat}

Analisis univariat bertujuan untuk mengetahui gambaran karakteristik responden yang meliputi jenis kelamin, usia dan pendidikan.

a. Jenis Kelamin

Distribusi frekuensi responden berdasarkan pendidikan dapat dilihat pada tabel berikut.

Tabel 1. Distribusi karakteristik responden berdasarkan jenis kelamin $(n=30)$

\begin{tabular}{clccc}
\hline No & \multicolumn{2}{c}{ Jenis Kelamin } & Jumlah (n) & Presentase (\%) \\
\hline 1 & Laki-laki & 6 & 20,0 \\
2 & Perempuan & 24 & 80,0 \\
\cline { 3 - 4 } & & Total & 30 & 100 \\
\hline
\end{tabular}

Berdasarkan hasil penelitian, mayoritas responden berjenis kelamin perempuan yaitu berjumlah 24 orang (80\%). Hasil tersebut sesuai dengan penelitian yang 
dilakukan menurut Refrensi [5] di Klinik Penyakit Dalam RSUD Arifin Achmad Pekanbaru, dalam penelitian nya menyatakan bahwa perempuan cenderung lebih tinggi untuk terkena Diabetes Melitus dibandingkan laki-laki dengan presentasi 63,3\%. Demikian pula penelitian Refrensi [7] di Puskesmas Jayabaru Kota Banda Aceh, menemukan bahwa presentase jumlah perempuan penyandang Diabetes Melitus sebanyak $87,7 \%$ lebih tinggi dari laki-laki.

Pada dasarnya, angka kejadian Diabetes Mellitus tipe 2 bervariasi antara laki-laki dan perempuan. Mereka mempunyai peluang yang sama terkena DM. Hanya saja dilihat dari faktor resiko, perempuan mempunyai peluang lebih besar diakibatkan peningkatan indeks massa tubuh (IMT) yang lebih besar. Sindroma siklus bulanan (premenstrual syndrome), pascamenopause yang membuat distribusi lemak tubuh menjadi mudah terakumulasi akibat proses hormonal tersebut sehingga wanita berisiko menderita Diabetes Melitus [7].

Menurut Refrensi [8] menyatakan bahwa perempuan lebih beresiko menderita DM tipe 2 di karenakan perempuan memiliki resiko lebih besar untuk menderita Diabetes Melitus dibandingkan laki-laki, hal ini berhubungan dengan kehamilan dimana kehamilan merupakan faktor resiko untuk terjadinya penyakit Diabetes Mellitus.

b. Usia

Distribusi frekuensi responden berdasarkan usia dapat dilihat pada tabel berikut.

Tabel2. Distribusi karakteristik responden berdasarkan usia $(n=30)$

\begin{tabular}{lccc}
\hline No & Usia & Jumlah (n) & Presentase (\%) \\
\hline 1 & $20-30$ & 0 & 0 \\
2 & $31-40$ & 5 & 16,7 \\
3 & $41-50$ & 13 & 43,3 \\
4 & $51-60$ & 12 & 40,0 \\
\hline & & 30 & 100 \\
\hline
\end{tabular}

yang dilakukan oleh Refrensi [5] di Klinik

Penelitian terhadap 30 orang Penyakit Dalam RSUD Arifin Achmad responden menunjukkan hasil bahwa Pekanbaru, dalam penelitiannya mayoritas umur 40-50 tahun (50\%). Hasil menunjukkan bahwa mayoritas responden yang sama juga diperoleh pada penelitian berumur 45-60 tahun (53,3\%). Demikian 
pula penelitian Refrensi [8] di Poliklinik Endokrin RSUP Prof. Dr. R. D. Kandou Manado memperlihatkan mayoritas responden berumur 40-60 tahun $(92,1 \%)$.

Sejalan dengan hasil penelitian [10] menunjukkan bahwa terdapat hubungan bermakna antara umur dengan kejadian DM tipe 2 dan menyatakan bahwa orang dengan umur $\geq 45$ tahun memiliki risiko 8 kali lebih besar terkena penyakit DM Tipe 2 dibandingkan dengan orang yang berumur kurang dari 45 tahun. Umur merupakan faktor berpengaruh pada orang dewasa, dengan semakin bertambahnya umur kemampuan jaringan mangambil glukosa darah semakin menurun.

Menurut Refrensi [11] usia lebih dari 40 tahun adalah usia yang beresiko terkena DM tipe 2 dikarenakan adanya intolenransi glukosa dan proses penuaan yang menyebabkan kurangnya sel beta pankreas dalam memproduksi insulin.

c. Pendidikan

Distribusi frekuensi responden berdasarkan pendidikan dapat dilihat pada tabel berikut.

Tabel3. Distribusikarakteristikrespondenberdasarkanpendidikan $(n=30)$

\begin{tabular}{ccccc}
\hline No & & Pendidikan & Jumlah (n) & Presentase (\%) \\
\hline 1 & SMP & & 21 & 70,0 \\
2 & SMA & & 9 & 30,0 \\
& & & & 100
\end{tabular}

Pada penelitian ini menunjukkan bahwa mayoritas pendidikan responden adalah SMP yang berjumlah 21 orang (70\%). Penelitian ini sejalan dengan penelitian yang dilakukan oleh Refrensi [8] tahun 2016 di Puskesmas Ranotana Weru Kota Manado, menyatakan jurnal penelitian [5] menyatakan bahwa latar responden yang berpendidikan rendah sebanyak $87 \%$.

Beberapa penelitian yang pernah kemampuan untuk memahami faktor-faktor dilakukan menjelaskan bahwa tingkat yang berkaitan dengan penyakit dan pendidikan mempunyai pengaruh terhadap menggunakan pengetahuan tersebut untuk

kesehatan. Orang yang memiliki tingkat pendidikan tinggi biasanya memiliki pengetahuan tentang kesehatan sehingga orang akan memiliki kesadaran dalam menjaga kesehatan [11].

Menurut Potter dan Perry (2005) dalam belakang pendidikan akan membentuk cara berpikir seseorang termasuk membentuk 
menjaga kesehatan. Hal ini didukung dengan pernyataan Refrensi [12], semakin tinggi tingkat pendidikan seseorang maka semakin tinggi pemahamannya, sehingga tingkat pendidikan sangat berperan dalam penyerapan dan pemahaman terhadap informasi.

Namun perlu ditekankan bahwa seseorang berpendidikan rendah tidak berarti memiliki pengetahuan yang rendah pula. Menurut Erfandi (2009) dalam Refernsi [13] menyatakan bahwa pengetahuan tidak hanya didapatkan melalui pendidikan formal tetapi dapat diperoleh dari pendidikan non formal. Pengetahuan yang diperoleh baik dari pendidikan formal maupun non formal dapat memberikan pengaruh jangka pendek (immediate impact) sehingga menghasilkan perubahan atau peningkatan pengetahuan, didukung dengan media massa dan metode yang digunakan dalam proses pendidikan maka penerimaan informasi pengetahuan lebih mudah untuk dipahami.

\section{AnalisisBivariat}

Analisis bivariat dilakukan untuk mengetahui perbedaan pengetahuan dan kemampuan dalam melakukan senam kaki. Sebelum dilakukan analisis bivariat harus dilakukan uji normalitas pada data untuk mengetahui data berdistribusi normal, pada data ini dilakukan uji normalitas menggunakan kolmogorov-smirnov dengan syarat data responden tidak boleh $>50$ orang. Hasildariujikolmogorov-smirnov nilai $p>0,05$. Setelah data diketahui berdistribusi normal maka uji statistik yang digunakan uji parametrik paired t-test. Hasil uji disajikan dalam bentuk tabel sebagai berikut :

a. Perbedaan pengetahuan tentang senam kaki pada penderita Diabetes Melitus Tipe 2 sebelum dan sesudah diberikan edukasi melalui media audiovisual dan metode demonstrasi.

Distribusi frekuensi responden berdasakan tingkat pengetahuan sebelum dilakukan edukasi dapat dilihat pada tabel berikut. 


\section{ARTIKEL PENELITIAN}

Tabel 4. Distribusifrekuensiberdasarkanpengetahuansebelumdilakukanedukasi $(n=30)$

\begin{tabular}{cccc}
\hline No & Tingkat Pengetahuan & Jumlah $(\mathbf{n})$ & Presentase (\%) \\
\hline 1 & Baik & 0 & 0 \\
2 & Cukup & 0 & 0 \\
3 & Kurang & 30 & 100 \\
\hline & Total & 30 & 100
\end{tabular}

lakukan edukasi dalam penelitian ini dapat Sedangkan distribusi frekuensi responden dilihat pada table berikut: berdasarkan pengetahuan sesudah di

Tabel 5. Distribusifrekuensiberdasarkanpengetahuansetelahdilakukanedukasi $(n=30)$

\begin{tabular}{cccc}
\hline No & Tingkat Pengetahuan & Jumlah $(\mathbf{n})$ & Presentase $(\%)$ \\
\hline 1 & Baik & 6 & 20,0 \\
2 & Cukup & 19 & 63,3 \\
3 & Kurang & 5 & 16,7 \\
\hline & Total & 30 & 100 \\
\hline
\end{tabular}

Dari hasil analisis pada kedua table diatas, sebelum dan sesudah diberikan edukasi perbedaan pengetahuan tentang senam dapat dilihat pada table berikut ini: kaki pada penderita Diabetes Melitus Tipe 2

Tabel 6. Perbedaan pengetahuan tentang senam kaki pada penderita Diabetes Melitus Tipe 2 sebelum dan sesudah diberikan edukasimelalui media audiovisual dan metode demonstrasi $(n=30)$

\begin{tabular}{lccccc}
\hline \multicolumn{1}{c}{ Variabel } & Mean & SD & SE & p value & N \\
\cline { 1 - 4 } Pre Test & 29,33 & 9,803 & 1,790 & \multirow{2}{*}{0,000} & \multirow{2}{*}{30} \\
\cline { 1 - 4 } Post Test & 65,33 & 10,743 & 1,961 & &
\end{tabular}

Hasil analisis pengaruh pemberian pengetahuan tentang senam kaki pada edukasi senam kaki dengan media penderita Diabetes Melitus Tipe 2 diketahui audiovisual dan demonstrasi terhadap terdapat peningkatan hasil test sebelum dan 
sesudah diberikan intervensi. Hasil uji Paired T-Test pada satu kelompok dengan pre dan post test sesudah diberikan edukasi senam kaki diperoleh $p$ value $(0,000)<\alpha \quad(0,05)$ sehingga diketahui terdapat peningkatan pengetahuan yang signifikan.

Penelitian ini sejalan dengan penelitian yang dilakukan oleh [5] menyebutkan bahwa terdapat pengaruh pendidikan kesehatan senam kaki melalui media audiovisual terhadap pengetahuan pelaksanaan senam kaki pada pasien DM Tipe 2.

Referensi

mengatakan pengetahuan merupakan hasil tahu seseorang terhadap objek melalui indera yang dimilikinya (mata, hidung, telinga, dan sebagainya). Menurut referensi [14] mengatakan sebagian besar pengetahuan manusia diperoleh melalui mata dan telinga seperti informasi yang berupa tulisan dan informasi yang berbentuk suara seperti video yang membantu menstimulasi pengindraan proses pembelajaran.

Edukasi yang dilakukan kepada responden mempengaruhi pengetahuan tentang senam kaki karena edukasi merupakan proses interaktif yang mendorong terjadinya pembelajaran. Pembelajaran merupakan upaya penambahan pengetahuan, sikap, dan keterampilan melalui penguatan praktik dan pengalaman tertentu [15].
Pemberian edukasi yang diberikan kepada responden didukung dengan penggunaan media. Jenis media edukasi yang digunakan termasuk pada jenis media audiovisual, menurut Refrensi [16] media audiovisual mempunyai unsur suara dan unsur gambar yang bisa dilihat seperti yang digunakan pada peneltian ini berupa vidio yang dapat merangsang indera penglihatan dan pendengaran. Menurut Juliantara (2010) dalam referensi [17] menyatakan bahwa sebagai alat bantu media pembelajaran media audiovisual mempunyai sifat untuk meningkatkan persepsi, pengertian, memberikan penguatan atau pengetahuan hasil yang dicapai serta media audiovisual memberikan pengalaman langsung dan membuat pembelajaran menjadi lebih menyenangkan.

Selain penggunaan media, pengetahuan dipengaruhi oleh beberapa faktor salah satunya menurut referensi [18] dalam penelitian Refrensi [5] menyatakan faktor yang mempengaruhi pengetahuan diantaranya pendidikan dan umur. Hal ini dapat dilihat dari karakteristik responden, dalam penelitian menunjukkan bahwa mayoritas responden berpendidikan SMP sebanyak 21 orang $(70 \%)$ dengan rata-rata nilai 29,33 sebelum dilakukan intervensi dan nilai rata-rata meningkat menjadi 65,33 sesudah diberikan intervensi. Beberapa 
penelitian yang pernah dilakukan menjelaskan bahwa tingkat pendidikan mempunyai pengaruh terhadap kesehatan. Menurut Potter dan Perry (2005) dalam jurnal penelitian [5] menyatakan bahwa latar belakang pendidikan akan membentuk cara berpikir seseorang termasuk membentuk kemampuan untuk memahami faktor-faktor yang berkaitan dengan penyakit dan menggunakan pengetahuan tersebut untuk menjaga kesehatan. Hal ini didukung dengan pernyataan Refrensi [19] yang menyebutkan bahwa semakin tinggi tingkat pendidikan seseorang maka semakin tinggi pemahamannya, sehingga tingkat pendidikan sangat berperan dalam penyerapan dan pemahaman terhadap informasi.

Sejalan dengan teori Refrensi [18] menyatakan bahwa umur mempengaruhi terhadap daya tangkap dan pola pikir seseorang. Semakin bertambah umur akan semakin berkembang pula daya tangkap dan pola pikirnya, sehingga pengetahuan yang diperolehnya semakin membaik serta semakin tua semakin berpengalaman, semakin banyak informasi yang dijumpai dan semakin banyak hal yang dikerjakan sehingga menambah pengetahuannya.

b. Perbedaan kemampuan dalam melakukan senam kaki pada penderita Diabetes Melitus Tipe 2 sebelum dan sesudah diberikan edukasi melalui media audiovisual dan metode demonstrasi

Distribusi frekuensi responden berdasakan kemampuan melakukan senam kaki sebelum dilakukan edukasi dapat dilihat pada tabel berikut:

Tabel 7.Distribusi frekuensi responden berdasarkan kemampuanmelakukansenam kaki sebelumdilakukanedukasi $(n=30)$

\begin{tabular}{cccc}
\hline No & Tingkat Kemampuan & Jumlah (n) & Presentase (\%) \\
\hline 1 & Sangat Baik & 0 & 0 \\
2 & Baik & 0 & 0 \\
3 & Cukup Baik & 0 & 0 \\
4 & Tidak Baik & 30 & 100 \\
\hline \multicolumn{4}{c}{ Total } \\
Sedangkan distribusi frekuensi responden & senam kaki sesudah di lakukan edukasi \\
berdasarkan kemampuan melakukan & dalam penelitian ini dapat dilihat pada table
\end{tabular}


Tabel 8. Distribusi frekuensi responden berdasarkan kemampuanmelakukansenam kaki setelahdilakukanedukasi $(n=30)$

\begin{tabular}{cccc}
\hline No & Tingkat Kemampuan & Jumlah $(\mathbf{n})$ & Presentase (\%) \\
\hline 1 & Sangat Baik & 4 & 13,3 \\
2 & Baik & 12 & 40,0 \\
3 & Cukup Baik & 12 & 40,0 \\
4 & Tidak Baik & 2 & 6,7 \\
\hline & Total & 30 & 100 \\
\hline
\end{tabular}

Dari hasil analisis pada kedua tabeld iatas, sebelum dan sesudah diberikan edukasi perbedaan kemampuan melakukan senam dapat dilihat pada table berikut ini: kaki pada penderita Diabetes Melitus Tipe 2

Tabel 9. Perbedaan kemampuan dalam melakukan senam kaki pada penderita Diabetes Melitus Tipe 2 sebelum dan sesudah diberikan edukasi melalui media audiovisual dan metode demonstrasi $(n=30)$

\begin{tabular}{lccccc}
\hline \multicolumn{1}{c}{ Variabel } & Mean & SD & SE & $\boldsymbol{p}$ value & N \\
\cline { 1 - 4 } Pre Test & 0,00 & 0,000 & 0,000 & \multirow{2}{*}{0,000} & 30 \\
\cline { 1 - 4 } Post Test & 71,00 & 16,324 & 2,980 & & \\
\hline
\end{tabular}

Hasil analisis pengaruh pemberian yang dilakukan oleh Refrensi [5] edukasi senam kaki dengan media audiovisual menyimpulkan bahwa terdapat pengaruh dan demonstrasi terhadap kemampuan pendidikan kesehatan senam kaki melalui melakukan senam kaki pada penderita Diabetes Melitus Tipe 2 diketahui terdapat peningkatan hasil test sebelum dan sesudah diberikan intervensi. Hasil uji Paired T-Test pada satu kelompok dengan pre dan post test selain mempengaruhi pengetahuan juga setelah diberikan edukasi senam kaki mempengaruhi kemampuan dalam melakukan diperoleh $\mathrm{p}$ value $(0,000)<\alpha(0,05)$ sehingga senam kaki karena dalam edukasi terjadi diketahui terdapat peningkatan kemampuan proses pembelajaran yang menghasilkan yang signifikan.

perubahan tingkah laku [21]. Bentuk perubahan tingkah laku dari hasil proses 
pembelajaran yang dialami responden adalah kemampuannya melakukan senam kaki.

Dalam proses pembelajaran diperlukan sebuah media dan metode khusus untuk mencapai tujuan pembelajaran yang efektif dan efisien [22]. Dalam proses pembelajaran penggunaan sebuah media dapat memberikan pandangan nyata terhadap apa yang akan dipelajari. Media yang digunakan dalam penyampaian senam kaki yaitu media audiovisual berupa sebuah vidio.Metode yang digunakan pada penelitian ini yaitu metode demonstrasi, metode ini bermanfaat untuk membuat responden lebih tertarik dengan apa yang diajarkan, menjadi lebih fokus dan terarah pada materi, dan pengalaman terhadap pengajaran lebih diingat dengan baik oleh responden [22]. Hal ini juga sejalan dengan penelitian Refrensi [23] menyatakan ada pengaruh pendidikan kesehatan dengan metode demonstrasi terhadap kemampuan merawat kaki pada penderita Diabetes melitus.

\section{KESIMPULAN}

Pemberian edukasi senam kaki dengan menggunakan media audiovisual dan metode demonstrasi dapat meningkatkan pengetahuan dan kemampuan penderita Diabetes Melitustipe 2 dalam melakukan senam kaki. Penggunaan media audiovisual dan metode demonstrasi ini dapat digunakan oleh perawat di Puskesmas sebagai upaya promotif dan preventif terhadap komplikasi terjaidnya ulkus diabetes sehingga kulitas hidup penderita penderita Diabetes Melitustipe 2 dapat ditingkatkan.

\section{DAFTAR PUSTAKA}

1. Suyono, Slamet. 2009. Penatalaksanaan Diabetes Melitus Terpadu. Jakarta:FKUI

2. WHO. 2016. "Global Report On Diabetes. (Online)".Abstrakdiunduhdari(http://apps.w ho.int/iris/bitsream/10665/204871/1/97892 41565257 eng.pdf?ua=1) diakses pada tanggal $12 / 12 / 2017$

3. Wulandari, Octaviana dan Martini, Santi. 2013. Perbedaan Kejadian Komplikasi Penderita Diabetes Melitus Tipe 2 Menurut Gula Darah Acak. Jurnal berkala Epidemiologi Volume 1 No. 2 : hal 182191

4. Wahyuni, Aria \&Arisfa, Nina. 2016. Senam Kaki Diabetik Efektif Meningkatkan Ankle Brachial Index Pasien Diabetes Melitus Tipe 2. Jurnal Ipteks Terapan, Research of Applied Science and Education V9.i2 hal : 155-164

5. Dari, Novelia Wulan dkk. 2014. Pengaruh Pendidikan Kesehatan Senam Kaki Melalui Media Audiovisual Terhadap Pengetahuam Pelaksanaan Senam Kaki Pada Pasien DM tipe 2. JOM PSIK Volume 1 No. 2 : hal 1 - 7 
6. Indey, K. (2012). Penyuluhan Kesehatan Dengan Media Audio Visual Terhadap Penurunan Tingkat Kecemasan Pada Pasien $D M$. (Online).

Abstrakdiunduhdari(http://apps.umsurabay a.ac.id/digilib/files/diaksespadatanggal 12/12/2017.

7. Ramadhan, Nur dkk. 2015. Karakteristik Penderita Diabetes Mellitus Berdasarkan Kadar HBA1C Di Puskesmas Jayabaru Kota Banda Aceh. Jurnal Kesehatan SEL Volume 2 No. 2 : hal 49-56

8. Allorerung, Desy L dkk. 2016. Hubungan Antara Umur, Jenis Kelamin dan Tingkat Pendidikan Dengan Kejadian Diabetes Mellitus Tipe 2 di Puskesmas Ranotana Weru Kota Manado. (Online). Abstrakdiunduhdari(http//:medkesfkm.unsr at.ac.id). Diakses pada tanggal 24/5/2018

9. Panelewen, Rian dkk. 2017. Hubungan Usia Penyandang Diabetes Mellitus Tipe 2 dan Disfungsi Ereksi. Jurnal e-Biomedik Volume 5 N0. 2 hal 1-5

10. Kekenusa, J. S. (2013). Analisis Hubungan Antara Umur Dan Riwayat Keluarga Menderita Dm Dengan Kejadian Penyakit Dm Tipe 2 Pada Pasien Rawat Jalan Di Poliklinik Penyakit Dalam Blu Rsup Prof. Dr. R.d Kandou Manado.(Online).Abstrakdiunduhdari (http://etd.eprints.ums.ic.id). Diakses pada tanggal 24/5/2018
11. Trisnawati, Shara K, Soedijono S. 2013. Faktor Risiko Kejadian Diabetes Melitus Tipe II di Puskesmas Kecamatan Cengkareng Jakarta Barat Tahun 2012. Jurnal IImiah Kesehatan Volume 5 No.1 Hal : 6-11

12. Mamangkey, Isabella V dkk. 2013. Hubungan Antara Tingkat Pendidikan dan Riwayat Keluarga Menderita Diabetes Melitus dengan Kejadian Diabetes Melitus Tipe 2 Pada Pasien Rawat Jalan Di Poliklinik Penyakit Dalam BLU RSUP Prof.

Dr. R. D. Kandou Manado. (Online).Abstrakdiunduhdari (http:// fkm.unsrat.ac.id/wpcontent/uploads/2014/11/ARTIKELIsabella.pdf). Diakses pada tanggal 24/5/2018

13. Notoadmojo, S. 2010. Metodelogi Penelitian kesehatan. Jakarta:PT Rineka Cipta

14. Yunita, Lulu. 2016. Efektivitas Pendidikan Kesehatan Dengan Metode Ceramah Terhadap Tingkat Pengetahuan Ibu Dalam Penanganan Diare Balita Di Sekitar UPT TPA Cipayung, Depok. Jakarta: Universitas Islam Negeri Syarif Hidayatullah

15. Efendy, dkk. 2009. Keperawatan Kesehatan Komunitas Teori Dan Praktik Dalam Keperawatan. Jakarta:Salemba Medika 
16. Smeltzer \& Bare. 2008. Textbook of Medical Surgical Nursing Vol.2.Philadelphia: Linppincott William \& Wilkins.

17. Sanjaya, Wina. 2010. Pembelajaran Dalam Implementasi Kurikulum Berbasis Kompetensi. Jakarta: Kencana

18. Purwono, Joni. 2014. Penggunaan Media Audio-Visual Pada Mata Pelajaran IImu Pengetahuan Alam Di Sekolah Menengah Pertama Negeri 1 Pacitan. Jurnal Teknologi Pendidikan Dan Pembelajaran, Volume 2 No. 2 : hal 127-144

19. Notoatmodjo,s. 2005. Metodologi penelitian kesehatan. Jakarta : PT Rineka Cipta
20. Notoatmodjo,

s.

2007.

Perilakukesehatandanilmu

perilaku, Jakarta: PT RinekaCipta

21. Budiningsih,

Asri.

2004.

BelajardanPembelajaran. Yogyakarta: RinekaCipta

22. Astuti, P. 2011. Pengaruh Edukasi Preoperasi Terstruktur Terhadap SelfEfficacy dan Perilaku latihan Post Operasi Pada Pasien Fraktur Ekstermitas Bawah dengan Pembedahan di Surabaya. Jakarta:Universitas Indonesia

23. Supriadi, Dedy dkk. 2013. Pengaruh Pendidikan Kesehatan Dengan Metode Demonstrasi Terhadap Kemampuan Merawat Kaki Pada Penderita Diabetes Melitus. Jurnal Manajemen Keperawatan Volume 1 No. $1 \mathrm{Hal}: 39-47$ 
